\title{
STUDI KOMPARATIF : KUALITAS HIDUP LANSIA YANG TINGGAL BERSAMA KELUARGA DAN PANTI
}

\author{
Suci Tuty Putri*, Lisna Anisa Fitriana, Ayu Ningrum, Afianti Sulastri \\ Program Studi Keperawatan FPOK Universitas Pendidikan Indonesia; \\ Jl. Dr. Setiabudi No.229 Bandung. *email : suci.putri04@gmail.com
}

\begin{abstract}
ABSTRAK
Jumlah populasi dan umur harapan hidup lanjut usia(lansia) semakin meningkat dari tahun ke tahun. Dengan meningkatnya umur harapan hidup maka sangat penting untuk memperbaiki kualitas hidup lansia. Kualitas hidup lansia dipengaruhi oleh faktor lingkungan sosial dimana ia tinggal, sehingga perlu diketahui secara pasti sejauh mana perbedaan tersebut mempengaruhi kualitas hidup lansia. Penelitian ini merupakan studi komparatif, dengan rancangan penelitian potong melintang (cross sectional). Penelitian bertujuan mengetahui perbandingan kualitas hidup lansia yang tinggal bersama keluarga dengan yang tinggal di panti jompo. Jumlah responden adalah 160 orang lansia yang terdiri dari 80 orang yang tinggal di panti dan 80 orang tinggal bersama keluarga di komunitas. Teknik pemilihan sampel adalah consecutive sampling Hasil uji statistik dengan Mann-Whitney $U$ test menunjukkan bahwa terdapat perbedaan yang bermakna antara tempat tinggal dengan kualitas hidup lansia yaitu domain kesehatan fisik pada QoL $(\mathrm{p}=0.000)$, dengan domain psikologik pada QoL( $p=0.000)$, dengan domain hubungan sosial pada $\mathrm{QoL}(\mathrm{p}=0.000)$ dan dengan domain lingkungan pada $\mathrm{QoL}(\mathrm{p}=0.000)$. Diharapkan hasil penelitian ini menjadi dasar penetapan program-program pemberdayaan lansia sehingga dapat meningkatkan kualitas hidup lansia.
\end{abstract}

Kata Kunci : Lansia, Kualitas hidup \& Pemberdayaan lansia

\begin{abstract}
Population rate and life expectancy of eldery people is getting increase year by year. Due to the increasing life expectancy then it`s important to improve their quality of life. The eldery`s quality of life is influenced by social enviroment where they live, therefore we need to know certainly how far that difference can influence quality of life. This research is a comparative study with cross sectional design. The purpose of this research is to know comparison of eldery quality of life who live at nursing home and who live with their family. The number of respondent are 160 eldery people which consist of 80 people stay at nursing home and 80 people stay with their family in community. Sampling method is consecutive sampling. The result of Mann-Whitney Statistic test showed that there is difference quality of life of eldery people who live in nursing home and live in their family at community which is physical health domain ( $p$ $=0.000)$, physicology domain $(p=0.000)$, social relation domain $(p=0.000)$, and enviroment domain $(p=$ 0.000). it's expected this researh can be a reference to improve empowerment programs for eldery people
\end{abstract}

Keyword : eldery people, quality of life \& empowerment

\section{PENDAHULUAN}

Hasil sensus penduduk tahun 2010 menunjukkan bahwa Indonesia termasuk lima besar negara dengan jumlah penduduk lanjut usia terbanyak di dunia yakni mencapai 18,1 juta jiwa pada 2010 atau $9,6 \%$ dari jumlah penduduk (menkokesra.go.id). Angka harapan hidup penduduk Indonesia (laki-laki dan perempuan) semakin meningkat dari 67,8 tahun pada periode 2000-2005 menjadi 69,8 tahun pada periode 20052010 (BPPN, 2005).

Peningkatan tersebut disebabkan oleh 
kemajuan Ilmu Pengetahuan dan Teknologi (IPTEK), terutama bidang kedokteran, termasuk penemuan obat-obatan seperti antibiotik yang mampu menyerap berbagai penyakit infeksi, berhasil menurunkan angka kematian bayi dan anak, memperlambat kematian, memperbaiki gizi dan sanitasi sehingga kualitas dan umur harapan hidup meningkat ( Nugroho, 2008 ). Akibatnya, jumlah penduduk lanjut usia semakin bertambah banyak, bahkan cenderung lebih cepat dan pesat.

Seiring dengan bertambahnya jumlah lansia, terdapat banyak permasalahan yang dialami lansia di antaranya tidak berpendidikan, tidak memperoleh akses kesehatan, tidak memiliki jaminan hari tua, tidak memiliki dukungan sosial dari keluarga atau teman untuk merawat mereka. Banyak lansia yang pada akhirnya harus mengalami berbagai masalah psikis maupun fisik, seperti patologis pada kondisi fisik seperti terserang berbagai penyakit kronis dan kondisi psikis seperti stress, depresi, kesepian bahkan sampai nekad melakukan upaya bunuh diri (Salamah, 2005). Hal tersebut menyebabkan perubahan pada kualitas hidup mereka.

Kualitas hidup menurut World Health Organization (WHO) adalah persepsi seseorang dalam konteks budaya dan norma sesuai dengan tempat hidup orang tersebut berkaitan dengan tujuan, harapan, standar dan kepedulian selama hidupnya (WHO, 1996). Kualitas hidup seseorang merupakan fenomena yang multidimensional. WHO mengembangkan sebuah instrumen untuk mengukur kualitas hidup seseorang dari 4 aspek yaitu fisik, psikologik, sosial dan lingkungan. Betapa pentingnya berbagai dimensi tersebut tanpa melakukan evaluasi sulit untuk menentukan dimensi mana yang penting dari kualitas hidup seseorang.

Kualitas hidup yang dipengaruhi oleh aspek sosial dan lingkungan berkaitan erat dengan lingkungan tempat tinggal lansia. Lansia pada umumnya tinggal bersama dengan keluarga, namun tidak sedikit lansia yang tinggal di panti jompo. Panti jompo merupakan salah satu tempat menampung atau merawat lansia. Panti jompo adalah salah satu bentuk pemerintah kepada masyarakat yang telah berusia lanjut. Dibanyak negara memasukkan lansia di panti jompo merupakan suatu gaya hidup, namun kita sebagai orang timur yang adat dan kebudayaannya masih kental, memelihara, menjaga dan merawat orang tua adalah suatu kewajiban. Dr. Samlee Pilianbangchang, Direktur WHO regional Asia
Tenggara menyatakan “ Berada dekat keluarga adalah tempat terbaik untuk menghabiskan masa tua. Panti jompo harus dijadikan pilihan terakhir jika lansia tidak dapat merawat dirinya sendiri" (detikHealth, 2012).

Beberapa penelitian menunjukkan penurunan kualitas hidup lansia di karenakan terjadinya proses penyakit (fisiologis) pada lansia, seperti penurunan kualitas hidup pada lansia dengan stroke, penurunan kualitas hidup lansia dengan penyakit diabetes mellitus. Namun belum banyak ditemukan penelitian mengenai bagaimana kualitas hidup lansia jika ditinjau dari aspek sosial dan lingkungan, padahal hal tersebut juga sangat berpengaruh terhadap kualitas hidup lansia.

Keperawatan merupakan ilmu yang holistik dimana memandang manusia dari seluruh aspek kehidupan yang mempengaruhinya, baik fisiologis, psikologis, sosial, spiritual. Sehingga pemahaman mengenai pengaruh lingkungan sosial terhadap kesehatan menjadi kajian yang penting untuk membantu penerapan implementasi asuhan keperawatan yang tepat. Dengan mengetahuinya kualitas hidup lansia di berbagai tatanan tempat tinggal, dapat menjadi bahan evaluasi menentukan program-program pemberdayaan lansia, sehingga benar-benar efektif dalam meningkatkan kualitas hidup lansia.memberi kesimpulan bahwa pemberian air minum secara adekuat akan mengarah pada pengurangan hari rawat di rumah sakit.

\section{METODE PENELITIAN}

Penelitian ini merupakan studi komparatif dengan pendekatan waktu cross sectional. Penelitian dilaksanakan pada bulan JuniSeptember 2014 di tiga tempat yaitu panti Budi Pertiwi Bandung, panti Senja Rawi Bandung dan kecamatan Sukasari Bandung.. Penelitian dilakukan untuk mengidentifikasi kualitas hidup lansia dengan menggunakan instrumen WHO QoL BREFf. 160 orang responden dipilih dengan teknik consecutive sampling yang terdiri dari 80 orang lansia yang tinggal di panti dan 80 orang lansia yang tinggal bersama keluarga. Analisis statistik yang digunakan yaitu univariat, bivariat dengan Mann-Whitney $U$ untuk mengetahui perbedaan kualitas hidup lansia yang tinggal di panti dan bersama keluarga.

\section{HASIL PENELITIAN}


Dari penelitian yang dilakukan kepada 160 responden didapatkan bahwa gambaran umum usia responden sebagian besar berada pada kelompok umur 60-74 tahun sebanyak 52 orang (66\%) di panti dan 66 orang $(82,5 \%)$ di komunitas, sehingga lansia masih bisa beraktivitas. Berdasarkan tingkat pendidikan, sebagian besar responden berpendidikan SD 60\% tinggal di panti dan 62,5\% tinggal bersama keluarga di komunitas, tapi jika dibandingkan tingkat pendidikan lansia yang tinggal bersama keluarga yang berpendidikan SMP dan SMA lebih banyak daripada lansia di panti. pernikahan, penghasilan, hubungan dengan orang lain, dan standar referensi.

Coons dan Kaplan (Chairani, 2013) mengatakan bahwa setiap orang memiliki kualitas hidup yang berbeda tergantung dari masingmasing individu dalam menyikapi permasalahan yang terjadi dalam dirinya. Jika menghadapi dengan positif maka akan baik pula kualitas hidupnya, tetapi lain halnya jika dihadapi dengan negatif maka akan buruk pula kualitas hidupnya. Menurut Wagner mengatakan bahwa usia memengaruhi tingkat kualitas hidup seseorang sehingga lansia masih bisa beraktivitas. Ini sesuai

Tabel 1.1. Distribusi Frekuensi dan Prosentase Berdasarkan Data Demografi Responden yang Tinggal di Panti dan bersama Keluarga $(n=160)$

\begin{tabular}{lcccc}
\hline \multirow{2}{*}{ Data Demografi } & \multicolumn{2}{c}{ Panti } & \multicolumn{2}{c}{ Keluarga } \\
\cline { 2 - 5 } & F & \% & f & \% \\
\hline Usia & & & & \\
60-74 tahun & 52 & 65,0 & 66 & 82,5 \\
75-89 tahun & 28 & 35,0 & 14 & 17,5 \\
\hline Pendidikan Terakhir & & & & \\
SD & 48 & 60,0 & 50 & 62,5 \\
SMP & 10 & 12,5 & 17 & 21,3 \\
SMA & 6 & 7,5 & 7 & 8,8 \\
Diploma & 2 & 2,5 & 0 & 0,0 \\
Dll & 3 & 3,8 & 1 & 1,3 \\
Tidak Sekolah & 11 & 13,8 & 5 & 6,3 \\
\hline Jenis Kelamin & & & & \\
Laki-laki & 9 & 11,3 & 32 & 40,0 \\
Perempuan & 71 & 88,7 & 48 & 60,0 \\
\hline Masalah Kesehatan Sekarang & & & & \\
Hipertensi & 35 & 43,8 & 46 & 57,5 \\
Diabetes Mellitus & 1 & 1,3 & 5 & 6,3 \\
Gangguan Penglihatan & 4 & 5,0 & 7 & 8,8 \\
Rematik & 13 & 16,3 & 12 & 15,0 \\
Gangguan Pendengaran & 3 & 3,8 & 2 & 2,5 \\
Dll & 24 & 30 & 8 & 10,0 \\
\hline
\end{tabular}

\section{Uji Bivariat}

Analisa data uji bivariat menggunakan uji Mann-Whitney $U$. Sebelumnya data yang diperoleh di kelompokkan menjadi 3 kategori ordinal yaitu baik jika memiliki nilai $75-100$, cukup 50-75 dan kurang <50. Pada Tabel 1.2 di paparkan hasil dari analisa data berdasarkan .

Menurut WHO, kualitas hidup dipengaruhi oleh beberapa faktor diantaranya; jenis kelamin, usia, pendidikan, pekerjaan, status dengan hasil dari penelitian yang menunjukan bahwa usia mempengaruhi masing-masing domain(Chairani, 2013). Penelitian yang dilakukan oleh Wahl, dkk mengemukakan bahwa kualitas hidup akan meningkat seiring dengan lebih tingginya tingkat pendidikan yang didapatkan oleh individu. WahlRustoen, Hanestad, Lerdal, \& Moum menemukan bahwa baik pada pria maupun wanita, individu dengan status menikah atau kohabitasi memiliki kualitas hidup yang lebih tinggi(Ritonga, 2013). 
Table 1.2 Kualitas Hidup Lansia yang tinggal di Panti dan bersama Keluarga

\begin{tabular}{lccccccc}
\hline & \multicolumn{3}{c}{ Panti } & \multicolumn{3}{c}{ Keluarga } \\
\cline { 2 - 8 } Kualitas Hidup & Baik & Cukup & Kurang & Baik & Cukup & Kurang \\
\cline { 2 - 8 } & $(\mathbf{n = 2 )}$ & $\mathbf{( n = 8 6 )}$ & $(\mathbf{n = 2 3 2})$ & $(\mathbf{n = 1 0})$ & $(\mathbf{n = 2 3 1})$ & $(\mathbf{n = 7 9 )}$ \\
\hline Domain Fisik & $1,3 \%$ & $30,0 \%$ & $68,8 \%$ & $3,8 \%$ & $65,0 \%$ & $31,3 \%$ \\
\hline Domain Psikologis & $0,0 \%$ & $30,0 \%$ & $70,0 \%$ & $2,5 \%$ & $73,8 \%$ & $23,8 \%$ \\
\hline Domain Hub. Sosial & $0,0 \%$ & $20,0 \%$ & $80,0 \%$ & $2,5 \%$ & $67,5 \%$ & $30,0 \%$ \\
\hline Domain Lingkungan & $1,3 \%$ & $27,5 \%$ & $71,3 \%$ & $3,8 \%$ & $82,5 \%$ & $13,8 \%$ \\
\hline
\end{tabular}

\section{Perbedaan Kualitas Hidup Lansia Yang Tinggal Bersama Keluarga dan Tinggal di Panti}

Tabel 1.2 menunjukan bahwa pada domain fisik lansia yang tinggal di panti sebagian besar $(68,8 \%)$ memiliki kualitas hidup yang kurang, sedangkan lansia yang tinggal bersama keluarga sebagian besar $(65,0 \%)$ memiliki kualitas yang cukup. Pada domain psikologis, lansia yang tinggal di panti sebagian besar $(70,0 \%)$ memiliki kualitas hidup yang kurang, sedangkan yang tinggal bersama keluarga sebagian besar $(73,8 \%)$ memiliki kualitas hidup cukup. Pada domain hubungan sosial, lansia yang tinggal di panti sebagian besar $(80,0 \%)$ memiliki kualitas hidup yang kurang, sedangkan yang tinggal bersama keluarga sebagian besar $(67,5 \%)$ memiliki kualitas hidup yang cukup. Dan pada domain lingkungan, lansia yang tinggal di panti sebagian besar $(71,3 \%)$ memiliki kualitas hidup yang kurang, sedangkan yang tinggal bersama keluarga sebagian besar $(82,5 \%)$ memiliki kualitas hidup yang cukup.

Tabel 1.3 menunjukkan hasil uji statistik analisis bivariat yaitu terdapat perbedaan yang bermakna antara tempat tinggal dengan 4 domain kualitas hidup $(\mathrm{p}=0.000)$. Hasil menunjukkan pada domain psikologik ada perbedaan bermakna antara tempat tinggal dengan dalam kualitas hidup lansia $(\mathrm{p}=0.000)$. Berdasarkan teori psikososial Erickson, lansia berada pada tahap integritas yang merupakan suatu keadaan dimana seseorang telah mencapai penyesuaian diri terhadap berbagai keberhasilan dan kegagalan dalam hidupnya (Setyoadi, Noerhamdani \& Ermawati, 2010). Perubahan psikologi yang terjadi pada lansia antara lain perubahan fungsi sosial, perubahan peran sesuai dengan tugas perkembangannya, perubahan tingkat depresi serta perubahan stabilitas emosi (Damojo, 2004).

Lansia yang tinggal bersama keluarga di komunitas memliki kemandirian yang berbeda dengan lansia yang tinggal di panti. Lansia di komunitas merasa masih cukup mampu memenuhi semua kebutuhannya sendiri secara sosial ekonomi. Selain itu, lansia di komunitas masih terlibat langsung dalam aktivitas keluarga sedangkan lansia yang tinggal di panti merasa

Tabel. 1.3 Hasil Uji Statistics Mann Whitney U

\begin{tabular}{|l|r|r|r|r|}
\hline & Domain1 & Domain2 & Domain3 & Domain4 \\
\hline $\begin{array}{l}\text { Mann- } \\
\text { Whitney U }\end{array}$ & 1571.000 & 1553.000 & 1231.000 & 738.500 \\
Wilcoxon & 4811.000 & 4793.000 & 4471.000 & 3978.500 \\
W & -5.588 & -5.669 & -6.796 & -8.421 \\
Z & .000 & .000 & .000 & .000 \\
Asymp. Sig. \\
(2-tailed)
\end{tabular}

a. Grouping Variable: Tempat_tinggal

sudah tidak mampu lagi melakukan kegiatankegiatan berat sehingga mereka membutuhkan bantuan. Menurut Asosiasi Psikologi Amerika (American Psychological Association) menemukan bahwa salah satu dari empat kebutuhan psikologis tergantung yang membuat manusia bahagia adalah autonomy atau kemandirian, yaitu rasa bahwa apa yang dikerjakan adalah pilihan dan diperjuangkan oleh diri sendiri (Priana, 2004).

Domain hubungan sosial menunjukkan lansia yang berada di panti memiliki kualitas 
hidup yang kurang (80\%) sedangkan lansia yang tinggal bersama keluarga memiliki kualitas hidup cukup (67,5\%). Uji statistik lebih lanjut menunjukkan bahwa terdapat perbedaan yang bermakna $(\mathrm{p}=0.000)$ antara tempat tinggal dengan domain hubungan sosial dalam kualitas hidup lansia. Lansia yang berada di komunitas dipengaruhi oleh dukungan keluarga dan masyarakat, dukungan pada keluarga dan masyarakat yang kurang akan membuat lansia mengalami perubahan negative terhadap kehidupannya, dan sebaliknya bila dukungan keluarga dan masyarakat cukup baik maka akan membuat lansia mengalami perubahan yang positive dalam kehidupannya, kedua hal ini akan mempengaruhi kualitas hidup pada lansia (Potter\&Perry, 2005).

Lansia yang tinggal di komunitas memiliki kedekatan dengan keluarga dimana keluarga merupakan sumber dukungan emosional. Dukungan sosial yang diterima dari berbagai pihak tersebut akan berpengaruh terhadap kualitas hidup lansia (Setyoadi, Noerhamdani\&Ermawati, 2010) . Penelitian Risdianto (2009) menunjukkan ada hubungan tinggi atau signifikan antara dukungan sosial dengan kualitas hidup lanjut usia $(\mathrm{r}=0,632$ dengan $\mathrm{p}$ sebesar 0,001). Menurut Kuntjoro, untuk menjaga kesehatan baik fisik maupun kejiwaannya lansia justru tetap harus melakukan aktivitas-aktivitas yang berguna bagi kehidupannya. Ini termasuk jenis dukungan sosial yakni integrasi sosial memungkinkan lansia untuk memperoleh perasaan memiliki suatu kelompok yang memungkinkannya untuk membagi minat, perhatian, serta melakukan kegiatan yang sifatnya kreatif secara bersama-sama (Fitria, 2011).

Domain lingkungan menunjukkan lansia yang ada dipanti memiliki kualitas hidup kurang $(71,3 \%)$ sedangkan di yang tinggal bersama keluarga memiliki kualitas hidup cukup $(82,5 \%)$. Uji statistik lebih lanjut menunjukkan terdapat perbedaan yang bermakna $(p=0.000)$ antara tempat tinggal dengan domain lingkungan yang menjadi faktor penting dalam kualitas hidup lansia. Lingkungan tempat tinggal yang berbeda mengakibatkan perubahan peran lansia menyesuaikan diri. Bagi lansia, perubahan peran dalam keluarga, sosial ekonomi dan sosial masyarakat tersebut mengakibatkan kemunduran dalam beradaptasi dengan lingkungan baru dan berinteraksi dengan lingkungan sosialnya. Berbeda dengan lansia di komunitas, lansia yang tinggal dipanti akan mengalami paparan terhadap lingkungan dan teman baru yang mengharuskan lansia beradaptasi secara positive atau negative (Nuryanti, 2012).
Lansia yang berada dalam suatu lingkungan atau komunitas dipengaruhi tingkat pendidikan dan perekonomian yang memegang peranan penting dalam pemenuhan kebutuhan akan lingkungan yang layak dan memadai, di antaranya tersedianya tempat tinggal yang bersih dan sehat, ketersediaan informasi, transportasi dan keterjangkauan terhadap pelayanan kesehatan. Berbeda dengan lansia dipanti yang memiliki keterbatasan terhadap berbagai faktor yang dapat meningkatkan kualitas lingkungannya, baik dari segi informasi, transportasi, dan pengadaan lingkungan yang bersih dan sehat (Setyoadi, Noerhamdani \&Ermawati, 2010).

\section{SIMPULAN}

Hasil analisis bivariat menunjukkan terdapat perbedaan bermakna antara tempat tinggal lansia yaitu panti dan keluarga dengan kualitas hidupnya, yaitu pada domain fisik ( $\mathrm{p}=0.000$ ), domain psikologis $(\mathrm{p}=0.000)$, domain hubungan sosial $(\mathrm{p}=0.000)$, dan domain lingkungan $(\mathrm{p}=0.000)$

\section{SARAN}

1. Pemerintah dapat lebih mengembangkan program-program pemberdayaan bagi lansia, terutama di panti jompo, meliputi aspek pemenuhan kebutuhan fisik, kebutuhan psikologis, kebutuhan hubungan sosial, dan lingkungan

2. Adanya upaya screening secara menyeluruh terhadap status kesehatan lansia baik di Panti maupun di Komunitas.

3. Ada program keperawatan gerontik yang dapat membantu peningkatan kualitas hidup lansia.

\section{DAFTAR PUSTAKA}

Badan Perencanaan Pembangunan Nasional(BPPN), BPS, United Nations Population Fund. Proyeksi penduduk Indonesia 2000-2025. Jakarta. Bappenas, BPS,UNFPA;2005

Carod AJF, Egido JA, Gonzalez JL, De Seijas EV. (2000). Quality of life among stroke survivors evaluated 1 year after stroke; Experiences of Stroke Unit. Stroke 31: 2995-3000 
Damojo BR(2004). Geriatri- Ilmu kesehatan lanjut usia bagi petugas kesehatan 1: kebijakan program Depkes RI.

Dorman P, Slattery J, Farrell B, Dennis M, \& Sandercock P. (1998). Qualitative comparison of the reliability of health status assessment with the EuroQol and SF-36 questionnaires after stroke. Stroke. 29: 6368 .

Elvina dkk. Perbedaan kualitas hidup lansia di rumah dan panti werdha di akses melalui https://lib.atmajaya.ac.id/default.aspx?tabI $\mathrm{D}=61 \& \mathrm{src}=\mathrm{k} \& \mathrm{id}=124555$. di akses tanggal 25 Februari 2014

Farquhar.M. (1995). Definition of Quality of Life. Journal of Advanced Nursing.22.502-503

Fayers MP \& Machin D (2000) Quality of Life Assessment: Analysis, and Interpretation. John Wiley \& Sons, LTD

Fitria. (2011). Interaksi sosial dan Kualitas hidup Lansia di Panti Wredha UPT Pelayanan Sosial Lanjut Usia dan Anak Balita Binjai. (Skripsi). Fakultas Ilmu Keperawatan, Universitas Padjadjaran

Garratt A, Schmidt L, Mackintosh A, \& Fitzpatrick R. (2002). Quality of life measurement: bibliographic study of patient assessed health outcome measures. $\mathrm{Br} \mathrm{Med}$ J. 324:1417-21

Guyatt GH, Feeny DH, \& Patrick DL.(1993). Measuring health-related quality of life. Ann Intern Med. 118:622-629

(2012). Mana Lebih baik hidup di panti jompo atau tinggal dengan anak saat tua. Di akses melalui http://health.detik.com/read/2012/09/10/092 427/2013019/763/

(2014). Jumlah Lansia Indonesia Lima Besar Terbanyak di dunia. Di akses melalui http://www.menkokesra.go.id/content/

Dayton,B.I,et.al.(2001).Psychological Well-Being Asian Style: The Perspective of Thai Elders.PSC Publications No. 01-474.

Momtaz A. Y.,et.al (2011). Sociodemographic predictors of elderly's psychological wellbeing in Malaysia.Aging \& Mental Health.Vol. 15, No. 4, 437-445.
Nugroho,W (2008) Keperawatan Gerontik \& Geriatrik. Jakarta: EGC.

Nuryanti T (2012). Hubungan Perubahan Peran Diri dengan Tingkat Depresi Lansia yang Tinggal di UPT PSLU Pasuruan.

Potter, P.A \& Perry, A.G (2005). Basic Nursing( 6 ${ }^{\mathrm{rd}}$ Ed). St. Louis Mosby Elsevier:

Priana MA. Identifikasi Faktor-faktor yang berhubungan dengan tingkat kemandirian petani dalam melakukan usaha agroforestri.Tesis. Institut Pertanian Bogor Program Pasca Sarjana

Salamah.(2005). Kondisi Psikis Dan Alternatif Penanganan Masalah Kesejahteraan Sosial Lansi Di Panti Wredha Jurnal. PKS.vol. iv no. $11,55-61$.

Salim, O,C., dkk. Validitas dan realibilitas World Health Organization Quality of Life-BREF untuk mengukur kualitas hidup lanjut usia. Jurnal Universa Medicina. Vol 26-No.1. 200

Sastroasmoro, S dan Ismael, S. (2008). Dasardasar metodologi penelitian klinis. (Ed.2). Jakarta: Sagung seto.

Setyoadi, Noerhamdani, Ermawati. (2010). Perbedaan Tingkat Kualitas hidup pada lansia wanita di komunitas dan panti. Di akses melalui http://ejournal.umm.ac.id/index.php/kepera watan/article/viewFile/621/641_umm_scien tific journal.pdf

The WHOQOL Group. Develeopment of WHOQOL; ratinoale and current status, Int J Mental Health 1994; 23 : 24-56

Ware JE \& Sheirbourne CD (1992). The MOS 36 item short form health survey (SF-36). Conceptual frame work and item selection. Med Care. Jun;30(6):473-83 